\title{
Polygonum sensu lato (Polygonaceae) in Australia
}

\author{
K.L. Wilson
}

\begin{abstract}
Wilson, K.L. (National Herbarium of New South Wales, Royal Botanic Gardens, Sydney, Australia 2000) 1988. Polygonum sensu lato (Polygonaceae) in Australia. Telopea 3(2): 177-182. - Polygonum has generally been used in a broad sense in Australia to include Fallopia, Persicaria and Reynoutria. In light of recent studies, these four groups are recognised as distinct genera. A key is provided to those genera at some time included in Polygonum but now regarded as distinct, that is, the above-mentioned genera plus Aconogonon, Bistorta, Fagopyrum and Koenigia. A list of these genera and of species recorded for Australia (whether native, naturalised or cultivated) is provided. New combinations are made for Persicaria decipiens ( $\mathrm{R}$. Br.) K.L. Wilson and P. subsessilis ( $\mathrm{R}$. Br.) K.L. Wilson.
\end{abstract}

\section{Introduction}

When Linnaeus established the genus Polygonum in 'Species Plantarum' (1753), he included in it species now assigned to seven different genera, viz. Aconogonon (Meissner) Reichb,, Bistorta Scop., Fagopyrum Miller, Fallopia Adans. emend. Holub, Persicaria Miller, Polygonum sens. strict. and Reynoutria Houtt. emend. Nakai. Various treatments of these genera, summarised by Haraldson (1978, Table 8), have been used since 1753, usually with sectional rank given to those included in Polygonum sens. lat. All have been treated as distinct genera by one author or another. Koenigia L. has been included in Polygonum in some treatments. Fagopyrum has generally been regarded as distinct, perhaps because of the economic significance and therefore familiarity of one of its species, $F$. esculentum Moench (Buckwheat).

There has been gradual recognition of the diversity within Polygonum: diversity not only in gross morphology but also in vegetative anatomy (Haraldson 1978) and in pollen morphology (Hedberg 1946). This has led to some authors accepting all the above-mentioned groups as genera (see, for example, Holub (1971), Hara $(1966,1982)$ ). Haraldson (1978) made a detailed study of subfamily Polygonoideae (the only subfamily present in Australia), in which she reviewed previous information and added more, especially on vegetative anatomy of the included taxa.

Haraldson used anatomical features of the stem, petiole, leaves and trichomes, as well as pollen and gross morphological characters, to develop her classification of the subfamily. In the case of Polygonum sens. lat. she concluded that some segregate genera were less closely related to Polygonum sens. strict. than to other genera (for example, Persicaria to Koenigia).

The evidence presented by Haraldson and earlier authors has led me to accept Polygonum in the narrow sense and to place in segregate genera the other species found in Australia. When this is done the only genera with Australian native species are Persicaria and Polygonum sens. strict., both of which also include naturalised species. Fagopyrum, Fallopia and Reynoutria are represented in Australia only by naturalised and cultivated species. 


\section{Segregate genera}

Traditional usage of Polygonum sens. strict. has been for the group of species commonly known as Wireweeds (e.g. P. aviculare L. and P. arenastrum Bor.). However, Börner (1913) chose Polygonum lapathifolium L. (belonging to Persicaria) as lectotype for Polygonum. McNeill (1981) proposed that Polygonum be conserved with $P$. aviculare as lectotype. Having been recommended for acceptance by the Committee on Spermatophyta (Taxon 33: 299 (1984)), this proposal was formally accepted at the XIV International Botanical Congress (1987).

The correct names for the segregate genera and their Australian species are listed in Table 1. The correct name for the lectotype species of Persicaria (Polygonum persicaria L.) appears to be Persicaria maculosa S.F. Gray rather than Persicaria maculata (Raf.) A. \& D. Löve or various other early names that have been suggested ( $\mathrm{J}$. McNeill, pers. comm.), but there is still some doubt about this. An earlier name that may displace it is Persicaria ruderalis (Salisb.) Reed, based on Polygonum ruderale Salisb.

Only two new combinations in the segregate genera are necessary for the species occurring in Australia. These are:

Persicaria decipiens (R. Br.) K.L. Wilson, comb. nov.

BASIOnYM: Polygonum decipiens R. Br., Prodromus: 420 (1810).

LECTOTYPE: (here designated): Port Jackson, R. Brown (Bennett/Britten no. 2995), 1804 (BM).

SYNONYM: Polygonum minus Hudson ssp. decipiens (R. Br.) Danser, Bull. Jard. Bot. Buitenzorg ser. 3, 8: 178 (1927).

This species has been confused in Australia with the annual European species Persicaria minor (Hudson) Opiz but is distinct from that species, differing in being perennial with often larger leaves $(5-12 \times 0.5-1.3 \mathrm{~cm}$; in $P$. minor, 2-7 x $0.4-0.9 \mathrm{~cm})$ and with the flower clusters in the spike-like inflorescence uniformly spaced (in $P$. minor, the clusters are much more distant towards the base of the inflorescence). However, it is very close to Persicaria salicifolia (Brouss. ex Willd.) Assenov (incl. Polygonum serrulatum Lag.) of Europe, Africa and South-West Asia, and study of more material may show that they are synonymous. Although this is uncertain, what is certain is the status of the species as a native in Australia, since Banks and Solander collected it at Botany Bay in 1770.

Table 1. Names accepted here for genera at some time previously included in Polygonum sens. lat., as well as for all species recorded for Australia (whether native, naturalised $\left({ }^{*}\right)$ or cultivated $(\dagger))$.

Polygonum L. sens. strict., nom. cons. [c. 50 spp., cosmopolitan; prob. introduced in many regions]

?*P. arenastrum Boreau

${ }^{*}$ P. argyrocoleon Steudel ex Kunze

?*P. aviculare L.

${ }^{*}$ P. patulum M. Bieb.

P. plebeium R. Br. 


\section{Accepted name}

Fagopyrum Miller, nom. cons.

[15 spp., in temperate Asia]

Sect. Fagopyrum

${ }^{*}$ F. esculentum Moench

Fallopia Adans. emend. Holub

[7 spp., native to northern temperate regions]

Sect. Fallopia

${ }^{*}$ F. convolvulus (L.) A. Löve

Sect. Pleuropterus (Turcz.) Haraldson

$\dagger$ F. baldschuanica (Regel) Holub

\section{Persicaria Miller}

[c. 150 spp., cosmopolitan but more common in N. Hemisphere]

\section{Sect. Persicaria}

P. attenuata (R. Br.) Soják

P. barbata (L.) H. Hara

P. decipiens (R. Br.) K.L. Wilson

P. elatior (R. Br.) Soják

P. hydropiper (L.) Spach

P. lapathifolia (L.) S.F. Gray

*P. maculosa S.F. Gray

$\doteqdot P$. odorata (Lour.) Soják

P. orientalis (L.) Spach

P. prostrata (R. Br.) Soják

P. subsessilis (R. Br.) K.L. Wilson

Sect. Echinocaulon (Meissner) Gross

$\mathrm{P}$. dichotoma (Blume) Masamune

P. praetermissa (Hook. f.) H. Hara

P. strigosa (R. Br.) Gross

Sect. Cephalophilon (Meissner) Gross

${ }^{*}$ P. capitata (Buch.-Ham. ex D. Don)

Gross

Sect. Tovara (Adans.) Gross

$\dagger$ P. filiformis (Thunb.) Nakai

Reynoutria Houtt. emend. Nakai

[c. 15 spp., native to Asia]

* R. japonica Houtt.

${ }^{*} R$. sachalinensis (Schmidt) Nakai

Aconogonon (Meissner) Reichb. [c. $10 \mathrm{spp}$. in N. Hemisphere]

\section{Bistorta Scop.}

[c. 7 spp. in N. hemisphere]

\section{Koenigia L.}

[c. 5 spp. in Asian mountains, 1 sp. arctic circumpolar \& Tierra del Fuego]
Name in Polygonum sens. lat.

$P$. sect. Fagopyrum

(Miller) DC.

P. fagopyrum L.

$P$. sect. Tiniaria Meissner

$P$. convolvulus $\mathrm{L}$.

P. sect. Pleuropterus (Turcz.) Benth. \& Hook. f.

P. baldschuanicum Regel

P. sect. Persicaria Meissn.

P. attenuatum $\mathrm{R}$. Br.

P. barbatum $\mathrm{L}$.

$P$. decipiens $\mathrm{R}$. $\mathrm{Br}$.

P. elatius $\mathrm{R} . \mathrm{Br}$.

P. hydropiper $\mathrm{L}$.

P. lapathifolium $\mathrm{L}$.

$P$. persicaria $\mathrm{L}$.

$P$. odoratum Lour.

$P$. orientale $\mathrm{L}$.

$P$. prostratum $\mathrm{R}$. Br.

P. subsessile $\mathrm{R}$. $\mathrm{Br}$.

P. sect. Echinocaulon Meissner

$P$. dichotomum Blume

$P$. praetermissum Hook. $\mathrm{f}$.

P. strigosum $\mathrm{R}$. Br.

$P$. sect. Cephalophilon Meissner

P. capitatum Buch.-Ham. ex D. Don

P. sect. Tovara (Adans.) Benth. \& Hook. f.

$P$. filiforme Thunb.

P. sect. Reynoutria (Houtt.) Nakai

P. cuspidatum Siebold \& Zucc.

$P$. sachalinense Schmidt

P. sect. Aconogonon Meissner

P. sect. Bistorta D. Don

P. sect. Koenigia (L.) Hook. f. 
Persicaria subsessilis (R. Br.) K.L. Wilson, comb. nov.

BAsIonym: Polygonum subsessile R. Br., Prodromus: 419 (1810).

LECTOTYPE (here designated): Iter Austral., R. Brown (Bennett/Britten no. 3000), 1802-1805 (BM). The collection site is unclear since the type sheet bears two field labels, one giving Port Dalrymple in Tasmania as the locality and the other Port Jackson in New South Wales (both regions are cited in the protologue).

SYNONYM: Polygonum minus ssp. subsessile (R. Br.) Danser, Bull. Jard. Bot. Buitenzorg ser. 3, 8: 176 (1927).

This species is related to Persicaria decipiens, but is quite distinct. $P$. subsessilis is generally a coarser plant than $P$. decipiens, and has white flowers (bright to pale pink or rarely white in $P$. decipiens) and is usually covered in coarse hairs $(P$. decipiens is glabrous apart from occasional fine hairs on leaf margins and veins and long cilia on the upper margin of the ocreae).

\section{Distinguishing features}

For practical discriminatory purposes, gross morphological features such as inflorescence structure, flower form, stigma form, leaf form and trichome arrangement are most useful. The distribution of most of these features can be seen in the following key, which is drawn largely from data in Haraldson's paper, especially Table 7. Genera occurring in Australia are in bold type.

1 Pit nectaries present at the base of the petiole. Outer three perianth segments enlarged and winged or keeled in fruit. [Leaves usually with an abscission zone at the base of the petiole.]

2 Stigmas shortly elongate, fimbriate. Flowers unisexual. Stout rhizomatous perennial herbs with erect annual stems. ................. Reynoutria

2* Stigmas capitate and smooth, or small-peltate and very shortly fimbriate. Flowers bisexual. Twining or decumbent slender but woody perennial herbs.

Fallopia

$1^{*}$ Pit nectaries absent. Perianth segments without enlarged wings or keels. [Stigmas capitate, smooth. Flowers bisexual.]

3 Ocreae deeply lacerate, silvery or white, glabrous. Flowers solitary or in small axillary clusters. Stamen filaments subulate above, broadly dilated in lower half. [Leaves usually with an abscission zone at base of petiole. Plants usually glabrous.]

Polygonum sens. strict.

3* Ocreae entire and tubular (often only shortly so and distintegrating with growth), pale brown to hyaline, glabrous or pubescent or with cilia on upper margin. Flowers in clusters or in paniculate, spike-like or capitate inflorescences. Stamen filaments uniformly subulate or filiform.

4 Nut greatly exceeding the perianth, at least twice as long, often winged on the angles. Leaves with abscission zone (occasionally hard to see) at base of petiole.

Fagopyrum

4* Nut enclosed by perianth, or shortly exceeding it (less than twice as long), not winged (or occasionally so in Aconogonon). Leaves without an abscission zone. 
5 Flowers in dense to lax, clearly defined, spike-like or capitate inflorescences.

6 Strongly rhizomatous perennial herbs with erect or ascending annual or perennial stems. Basal leaves strongly developed. Leaf margins revolute or rarely flat, mostly with prominent nerves on the curved portion.

Bistorta

$6^{*}$ Annual or perennial herbs, with erect to decumbent persistent stems, often rooting at the nodes, rarely with a slender rhizome. Leaves more or less evenly distributed along stems. Leaf margins flat or rarely revolute but always without prominent veins on the margin.

Persicaria

$5^{*}$ Flowers in diffuse small clusters or large loose panicle-like inflorescences.

7 Strongly rhizomatous perennial herbs with erect or flexuose annual stems. Nut occasionally winged. Aconogonon

$7^{*}$ Small erect or decumbent annuals. Nut not winged. Koenigia

The five genera found in Australia are readily distinguished on morphological features. For specimens in the vegetative state, the deeply lacerate, silvery or white, glabrous ocreae immediately distinguish species of Polygonum sens. strict. from those of the other genera, which have entire, tubular, pale brown to hyaline ocreae (often only very shortly tubular and disintegrating with growth) that may be pubescent, ciliate or glabrous. Occasionally species of Persicaria have a green limb of leaf-like texture on the upper margin of the ocrea. Plants of Polygonum are mostly quite glabrous, although extra-Australian species may occasionally bear two or the thirteen types of trichome that Haraldson (1978) recognised. Plants of the other genera generally bear at least some hairs of various types. The leaves of Polygonum, Fagopyrum, Fallopia and Reynoutria are distinctive in having an abscission zone (occasionally hard to see) at the base of the petiole. Pit nectaries ('Grubbennektarien' of Zimmerman, as detailed in Elias 1983) are found just below the abscission zone in Fallopia and Reynoutria. Salisbury (1909) described these nectaries, suggesting that their secretory activity played an important part in regulating the water-relations of the plant. A proposed alternative function for extra-floral nectaries (Bentley 1977) is that of attracting ants and hence protection of the plant by those ants against herbivorous animals. Bentley (1977) suggests that a protective function is more common than a strictly physiological function.

The genera differ in habit and habitat preferences. Persicaria species are generally erect to decumbent annuals or perennials with persistent stems often rooting at the nodes, rarely rhizomatous, and are mostly found in habitats seasonally or permanently wet. The other four genera are found in dryland habitats. Polygonum species are slender perennials, procumbent or decumbent or more rarely erect. Fagopyrum esculentum is an erect annual; extra-Australian species of Fagopyrum may be perennial and twining. Fallopia species are slender but somewhat woody twiners or decumbent. Reynoutria species are strongly rhizomatous herbaceous perennials, producing stout erect annual stems.

Flowers are bisexual except in Reynoutria, in which the functionally unisexual flowers may have vestiges of the other sex present. Cleistogamy occurs occasionally in Persicaria and Polygonum. The flowers are solitary or in small 
clusters in the leaf axils in Polygonum, with the flower-bearing stems mostly not readily distinguishable from vegetative stems; in the other genera the inflorescence-bearing axes are more clearly differentiated and the flowers are arranged in paniculate, spike-like or capitate inflorescences. Persicaria sect. Tovara (represented in Australia only by the cultivated $P$. filiformis) has a distinctive inflorescence: spike-like but very long, narrow and lax, with few flowers, which become deflexed soon after anthesis. The dispersal mechanism in section Tovara is unique in the family (Graham \& Wood 1965). The two styles become rigid and hooked at the apex and are persistent on the nut. The pedicel partly abscises so that any disturbance causes the mature fruit to separate from the plant and be catapulted up to $4 \mathrm{~m}$. The persistent hooked styles may enable further dispersal on the coats of animals.

In species of Fallopia and Reynoutria perianth segments are thin-winged or keeled and enlarged in fruit, completely enclosing the nut. In Persicaria the perianth segments also enclose the nut but are not markedly enlarged or winged. In contrast, the nut of Fagopyrum is at least twice as long as the perianth and may itself be winged. Stigma form varies from capitate and smooth in Persicaria and Polygonum to shortly elongate and fimbriate in Reynoutria (described as triangular by Haraldson 1978). In Fallopia the stigma is either capitate and smooth or small-peltate and very shortly fimbriate. Stamen filaments are subulate above and broadly dilated in the lower half in Polygonum; in the other genera they are uniformly subulate or filiform.

\section{References}

Bentley, B.L. (1977) Extrafloral nectaries and protection by pugnacious bodyguards. Ann. Rev. Ecol. Syst. 8: 407-427.

Börner, C. (1913) Botanisch-systematische Notizen. Abh. Naturwiss. Vereine Bremen: 245-282. [n.v.]

Elias, T.S. (1983) Extrafloral nectaries: their structure and function. Pp. 174-203 in B.L. Bentley \& T.S. Elias (eds), 'The Biology of Nectaries' (Columbia Univ. Press: New York).

Graham, S.A., \& C.E. Wood (1965) The genera of Polygonaceae in the southeastern United States. J. Arnold Arb. 46: 91-121.

Hara, H. (1966) 'The Flora of Eastern Himalya' (Univ. Tokyo Press: Tokyo).

Hara, H. (1982) Polygonaceae. In H. Hara et al. (eds), 'An enumeration of the flowering plants of Nepal'. Vol. 3: 172-180 (British Museum: London).

Haraldson, K. (1978) Anatomy and taxonomy in Polygonaceae subfam. Polygonoideae Meisn. emend. Jaretzky. Symb. Bot. Upsal. 22(2).

Hedberg, O. (1946) Pollen morphology in the genus Polygonum L. s. lat. and its taxonomical significance. Svensk Bot, Tidskr. 40: 371-404.

Holub, J. (1971) Fallopia Adans. 1763 instead of Bilderdykia Dum. 1827. Folia Geobot. Phytotax. 6: 171-177.

McNeill, J. (1981) Nomenclatural problems in Polygonum. Taxon 30: 630-641.

Salisbury, E.J. (1909) The extra-floral nectaries of the genus Polygonum. Ann. Bot. 23: 229-242, pl. 16.

Manuscript received 11 June 1986

Manuscript accepted 23 February 1987 


\section{$2 \mathrm{BHL}$ Biodiversity Heritage Library}

Wilson, Karen L. 1988. "Polygonum sensu lato (Polygonaceae) in Australia." Telopea: Journal of plant systematics 3(2), 177-182.

https://doi.org/10.7751/telopea19884806.

View This Item Online: https://www.biodiversitylibrary.org/item/264398

DOI: https://doi.org/10.7751/telopea19884806

Permalink: https://www.biodiversitylibrary.org/partpdf/281773

\section{Holding Institution}

The Royal Botanic Gardens and Domain Trust, New South Wales, Australia

\section{Sponsored by}

Atlas of Living Australia

\section{Copyright \& Reuse}

Copyright Status: In copyright. Digitized with the permission of the rights holder.

Rights Holder: The Royal Botanic Gardens and Domain Trust, New South Wales, Australia License: http://creativecommons.org/licenses/by-nc-sa/4.0/

Rights: http://biodiversitylibrary.org/permissions

This document was created from content at the Biodiversity Heritage Library, the world's largest open access digital library for biodiversity literature and archives. Visit BHL at https://www.biodiversitylibrary.org. 